\title{
Role of Self Help Groups in Rural Employments of India: A Case Study of Swarn Jayanti Gram Swarojgar Yojna
}

\author{
Dr.Archna Bundela ${ }^{1}$, Dr.Kamlesh Kumar Dubey ${ }^{2}$, Prof. Subodh Pande ${ }^{3}$ \\ ${ }^{I}$ Department of Economics, Dr. Harisingh Gour Central University Sagar, India, 470003 \\ ${ }^{2}$ Assistant Professor (Guest Faculty)Department of Economics, Dr. Harisingh Gour Central University Sagar. \\ ${ }^{3}$ Professor\& Head, Department of Economics, Dr. Harisingh Gour Central University Sagar, India, 470003
}

\begin{abstract}
Swarnajayanti Gram Swarojgar Yojana is an employment programme designed to stimulate selfemployment activities and ensure that every assisted Below Poverty Line (BPL) family - SWAROJGARI - is able to earn a minimum monthly income of 2000 within three years. It aims to achieve this objective by encouraging families to engage in income-generating activities and by providing assistance through a combination of wages, technical capacity building and a package of financial assistance that includes institutional credit and subsidy. In 1999, SGSY was formed from a merger and restructuring of the Integrated Rural Development Programme (IRDP) and allied skills generation programmes, namely Training for Rural Youth for Self Employment (TRYSEM), Development of Women and Children in Rural Areas (DWRCA), Supply of Toolkits in Rural Areas (SITRA), Ganga Kalyan Yojana (GKY) and Million Wells Scheme (MWS). Similar to the IRDP, the target group of SGSY consists of small and marginal farmers, agricultural labourers, rural artisans and others whose annual family income is less than the BPL income level. IRDP focused on credit provision to individual beneficiaries, while SGSY focuses on skills development of groups and clusters to improve the use of credit and asset acquisition. It promotes group activities that can increase forward and backward linkages and provide sustainable incomes.
\end{abstract}

Keywords: Rural Employment, Rural Economy, Rural Infrastructure, Market Economy, Gram Swarozgar

\section{INTRODUCTION}

Swarn Jayanti Gram Swarozgar Yojna started from April 1,1999. The scheme aims at establishing a large number of micro enterprises of rural employment programme. This is the only self employment program currently being implemented for rural people. The objective of SGSY is to bring the assisted poor family above the poverty line in 3 years by providing the am income generating assets through a mix of bank credit and government subsidy. The scheme of SGSY covers all aspects of self employment such as organization of the poor into Self Help Group training, technology, credit, infrastructure and marketing. Under SGSY, the beneficiaries are known as SWAROZGARES. The Swarozgaree is can be either individual or groups. SGSY lays emphasis on the group approach under which the rural poor are organized into Self Help Group (SHGs). SHG is a group of rural poor who have volunteered to organize themselves into a group for eradication of poverty of the members. They agree to save regularly and convert their savings into a common fund known as the Group the members of the group agree to use this common fund and such other funds that they may receive as a group through a common management.

\section{Formation of Self Help Group-}

Under the SGSY, generally a self help groups may consist of 10 to 20 persons and in case of minor irrigation and disabled persons, this number may be from 5-20. Generally all the members of the group should belong to families below poverty line however if necessary, a maximum of $20 \%$ and in exceptional cases, where essentially required up to a maximum of 30 percent of the members in a group may be taken from families imaginably above the poverty line living contiguously with BPL families and if they are acceptable to the BPL members of the group. However the above poverty line (APL) members will not be eligible for the subsidy under the scheme. The self help group should conduct regular meetings (weekly or fortnightly), functioning in a democratic manner, allowing free exchange of views, participation by the members in the decision making process.

The group should be able to collect the minimum voluntary saving amount from all the members regularly in the group meetings. The savings so collected will be the group corpus fund. The group corpus fund should be used to advance loans to the members. The group should develop financial management norms covering the loans, sanction procedure, repayment schedule and interest rate. The group should operate a group account preferably in their service areas bank branch so as to deposit the balance amounts left with the group after bursting loans to its members. The group should maintain simple basic records such as minute's book, 
attendance register loan ledger, cash book, pass book and individual pass books. 50 percent of the groups formed in each block should be exclusively for the women.

Table No.1

Distribution of loans and works allotted among Self-Help Groups under SGSY in Eleven blocks of Sagar district from year 2005 to 2010

\begin{tabular}{|c|c|c|c|c|c|c|c|c|c|}
\hline \multirow[b]{2}{*}{$\begin{array}{l}\text { S. } \\
\text { No. }\end{array}$} & \multirow[b]{2}{*}{$\begin{array}{l}\text { Blocks } \\
\text { Name }\end{array}$} & \multicolumn{2}{|c|}{ Primary Sector } & \multicolumn{2}{|c|}{ Secondary Sector } & \multicolumn{2}{|c|}{ Territory Sector } & \multicolumn{2}{|c|}{ Grand Total } \\
\hline & & $\begin{array}{l}\text { No. } \\
\text { of } \\
\text { SHGs }\end{array}$ & $\begin{array}{l}\text { Distribution } \\
\text { of loan }\end{array}$ & $\begin{array}{c}\text { No. } \\
\text { of } \\
\text { SHGs }\end{array}$ & $\begin{array}{l}\text { Distribution } \\
\text { of loan }\end{array}$ & $\begin{array}{l}\text { No. } \\
\text { of } \\
\text { SHGs }\end{array}$ & $\begin{array}{l}\text { Distribution } \\
\text { of loan }\end{array}$ & $\begin{array}{c}\text { Total } \\
\text { No. } \\
\text { of } \\
\text { SHGs }\end{array}$ & $\begin{array}{l}\text { Distribution } \\
\text { of loan (in } \\
\text { Lakhs) }\end{array}$ \\
\hline 1 & Sagar & 98 & $288,21,840$ & 16 & 3049000 & 20 & 2165000 & 134 & 34035840 \\
\hline 2 & Jaisinagar & 35 & 8953160 & 10 & 2568000 & - & - & 45 & 11521160 \\
\hline 3 & Rahatgarh & 66 & 20192410 & 07 & 1910000 & 02 & 448000 & 75 & 22550410 \\
\hline 4 & Khurai & 28 & 9535000 & 07 & 940000 & - & - & 35 & 10475000 \\
\hline 5 & Bina & 47 & 16770000 & 03 & 700000 & - & - & 50 & 17470000 \\
\hline 6 & Malthone & 11 & 6485000 & 09 & 1048000 & - & - & 20 & 7533000 \\
\hline 7 & Rehli & 58 & 21150000 & 23 & 3718000 & 13 & 1700000 & 94 & 26568000 \\
\hline 8 & Deori & 53 & 18180836 & 10 & 1705000 & 05 & 482000 & 68 & 20367836 \\
\hline 9 & Keshli & 63 & 20587000 & 05 & 968000 & - & 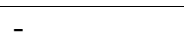 & 68 & 21555000 \\
\hline 10 & Banda & 30 & 10345000 & 24 & 3380000 & 12 & 3162000 & 66 & 16887000 \\
\hline 11 & Shahgarh & 34 & 10627000 & 26 & 5575000 & 05 & 950000 & 65 & 17152000 \\
\hline & Total & 523 & 171647246 & 140 & 25561000 & 57 & 8907000 & 720 & 206115246 \\
\hline
\end{tabular}

Source: Collected personally from the office records of Zila Panchayat, Sagar.

This scheme has been divided into three sectors i.e. Primary, Secondary and Territory sector to make the study more comprehensive:

- Primary Sector: The Primary Sector under SGSY includes rearing of Buffaloes, Pigs and Cows, Rearing of Goats, Poultry farm, Pisciculture, Small Irrigation, Horticulture (Nursery) and other works like Bullock Carts, Well maintenance, Agricultural activities etc.

- Secondary Sector: Secondary sector under SGSY includes making candles, agrabatties, bricks, handicrafts and food materials like making pickles, garam masala etc. small plantation and other such works like: $\mathrm{Dal} /$ Dalia production, Steel and Iron furniture industries, Manufacture of Rope, Cement production etc.

- Territory Sector: Territory sector under SGSY includes general stores, bicycle/motor repairing and binding carpenters, mason, ironsmith etc and other such works like Garment shop, shoe shop, tent house, tea stall, band party etc.

Table no.1 shows the details of distribution of loans and number of self help groups (SHGs) are formed and benefited by various works in three sectors i.e. primary, secondary and territory sectors, under Swarn jayanti Gram Swarozgar Yojana in eleven blocks of Sagar district from year 2005 to 2010.

1. Primary Sector: In primary sector, as shown in table no.1, that 523 Self Help Groups (SHGs) are benefited and total loans distributed among these 523 SHGs are Rs.17,16,47,246 in the eleven block of Sagar district from year 2005 to 2010 in this yojana.

In this sector maximum 98 Self Help Groups are benefited in Sagar block for various works and the loans distributed among them are Rs.28821840. And the minimum number of Self Help Groups are formed and benefited in Malthone block i.e., only 11 SHGs and the loans distributed in this block among 11 SHGs are Rs.64,85,000.

2. Secondary Sector: In secondary sector as shown in table no.1 that 140 Self Help Groups are benefited and loans distributed among them are Rs.25561000 in the eleven blocks of Sagar district.

In this sector maximum 26 Self Help Groups are benefited in Shahgarh block and the loans distributed among 26 SHGs are Rs.5575000. And the minimum 03 Self Help Groups are formed and benefited in Bina block and loans distributed among these SHGs are Rs.700000.

3. Territory Sectors: In territory sector as shown in the table no. 1 that 57 SHGs are formed and benefited in Sagar district and the loans distributed among them are Rs.8907000 from year 2005 to 2010.

In this sector, maximum 20 Self Help Groups are formed and benefited in Sagar block and the loans distributed among these 20 SHGs are Rs.2165000. The minimum 02 SHGs are formed and benefited in Rahatgarh block groups and the loans distributed among these 2 SHGs are Rs. 448000. 
It is also clear from the above table that in 5 blocks i.e., Jaisinagar, Khurai, Bina, Maltone and Kesli not a single Self Help Groups are formed in territory sector under Swarnjayanti Gram Swarozgar Yojana from year 2005 to 2010.

Thus, by including all the three sectors 720 Self Help Groups are formed and benefited in Sagar district and the total loans distributed in Sagar district is Rs.206115246, out of 720 SHGs maximum number of SHGs are benefited in Sagar block i.e., 134 and the loans distributed in Sagar block is Rs.3,40,35,840. The second largest SHGs are formed and benefited in Rehli block i.e., 94 and loans distributed in this block are Rs.26568000. The minimum 20 Self Help Groups are formed and benefited in Malthone block and whom Rs.7533000 loans has been distributed.

Out of 3 sectors, maximum 523 Self Help Groups are formed in primary sector and minimum 57 Self Help Groups are formed in territory sector in Sagar district, under this yojana from year 2005 to 2010.

\section{Problem under SGSY}

(i) During the survey it was found that it is difficult for an uneducated and poor people to make a project (key activities) for which they can apply loans under this Swarnjayanti Gram Swarozgar Yojana scheme for self-employment.

(ii). The corruption prevailing in the country plays the major role in finalizing the projects and the sanctioning of the loans. Almost 30 percent of the loans sanctioned goes as commission to the various levels of officers of this scheme and banks too. The person who has applied for the projects is badly affected. Therefore government should take some primitive action against corrupted officers.

(iii). As stated earlier that the loan under this scheme is sanctioned in installments. These Nationalized Commercial Banks after releasing the first installment of loans to beneficiaries under this scheme, they want the utilization certificate from these beneficiaries and only after getting this utilization certificate from the beneficiaries than the banks will release the second installment. Thus, this is again a hurdle in the implementation of this scheme.

(iv). I met certain beneficiaries of the Primary sectors during my survey. The primary sector includes rearing of buffaloes, cows; rearing of goats; pisciculture; poultry farm etc. One of beneficiary who were running poultry farm and other beneficiary who had taken loans for rearing of buffaloes, they told me because of the lack of insurance, if the chickens, or buffaloes dies, then this will affected a lot in their business (whole project) because they cannot repay the loans amount. Here it has suggested that some kind of insurance should also be provided to beneficiaries of the primary sector.

(v). During my survey, I met some of the beneficiaries of the secondary sectors, who were running their own business i.e. for making candles and agarbattis. They all complained about the marketing factor. They said that because their products are not branded the shop keeper give very little price of their product and these shop keepers sell at a higher price. It means no market benefit has been provided to these beneficiaries of secondary sector in this scheme.

(vi). The beneficiaries of territory sector under which general store, garments shops etc comes. Their complaints are some what different. These beneficiaries told me that their project is not very successful because they do not get the prime location in the market. Another beneficiary who had taken loans for stitching garments told that they do not get the best quality of sewing machine and also do not get sufficient cloth to manufacture the final items. This type of the problems of beneficiaries in this sector should also be looked by the government, who are monitoring this scheme.

(Vii). Some of the beneficiaries complaint that the rate of interest i.e. $12 \%$ is quiet high in this scheme.

(viii). Most of the beneficiaries told that the sanctioned loan is always less then what they have applied for, this is again the big hurdle in the smooth functioning of the scheme.

\section{Suggestions:}

Following are the suggestions for the improvement of this scheme:

(i) The first problem in the whole scheme is to make a project and do many formalities of Zila Panchayat and nationalized banks. To get their project approved, the majority of the rural population is unable to complete the long formalities and paper works for the approval of their projects. Here, it has been suggested that the Zila Panchayat through gram panchayat should advice and help the people in making their projects. They should also provide consultancy services to give demonstration and other such services to a common man in the village. The gram panchayat should also organize some workshop and asked the people to join it to complete the formalities which are required to run this scheme successful.

(ii) Sometimes the projects are approved by district as well as state level committee, may reject by central government which is also a big hurdle in the implementation of this scheme. 
Here it has been suggested again that the central government should give some authorities for the approval of the projects to the state level committee which will make the scheme easier for individuals and self help groups.

(iii) As already written above that most of the individuals and self help groups have complaint about the corruption at the different level of committee that is from village panchayat to central level committee including banks. Today corruption is everywhere i.e. from central government to gram panchayat. Corruption is a major problem that India is facing today; it is running the whole democratic system of India. If this corruption is not checked immediately, the whole democratic system in the country will collapse soon. The moral values of the society have gone down. It is evident in almost all sphere of life in India. Thus, government should take immediate step to check the corruption.

(iv) Another problem in this scheme is that the beneficiaries who were asking loans in the primary sector i.e. rearing of buffaloes, cows, rearing of goats, pisciculture etc. are not getting insurance. Because of this the people are now turning away for getting loans for these purposes.

Here suggested that the projects which sanctioned in the primary sectors under this scheme should get some insurance or subsidy to help the individuals or SHGs in case of some fatality of their animals.

(v) Another problem in this scheme is that the beneficiaries of secondary sector i.e. making candles, agarbatti, making garam masala etc. are not getting profit in their business, most of them are going in loss because their products are not branded and shopkeeper take their products at cheap rate.

Here suggested that the government should provide them market facilities through the public distribution system. Government should also organized handicraft fare, Haat (weekly market) etc. where these beneficiaries can sell their product and get profit out of it.

(vi) The beneficiaries of territory sectors who have taken loans for general store, tea stall, manufacturing of clothes etc. found that their business is not running in profit because of the lack of prime location in the market and due to high competition in the market itself.

It has been suggested that the government should provide good quality of machines, clothes and other things (commodities) to them. Government under this scheme should also sanction some limited amount for advertisement of their products through TV, Radio, Magazines and News paper. In almost every block there is a market of the Nagar Panchayat, to help these beneficiaries they should allot some of the shops to them.

(vii) Under this scheme, Government should decrease rate of interest little bit to make convenient for the beneficiaries so that they can return their loan on a monthly deposit on time.

(viii) Training should be given to all the beneficiaries of this scheme, though course work by Zila Panchayat in order to develop their skill.

(ix) The recovery of loans should be made easier.

(x) Government should also check timely that the beneficiaries are not misusing the loans amount under this scheme. If they are found, government should take some punitive action against them.

Finally, it can be concluded that though there are same problems like corruption pilferage of funds, very low utilization of loans etc. under this scheme but still if has been found that most of the beneficiaries are satisfied with this scheme. In our opinion SGSY is more or less successful in Sagar district.

\section{References:}

[1] Agrawal, A.N., Indian Economy, Weily Publishers, New Delhi, (1997), p. 345.

[2] Jhingan, M.L. Economics Development and Planning, Vrinda Publication Pvt. Ltd., Delhi, (1998), p. 422.

[3] Bohre, R.K. Rural Poverty and Unemployment in India, Northern Delhi, (2002), p. 58.

[4] Swarnjayanti Gram Swarozgar Yojna, General Features, Operational Guidelines (2008), Ministry of Rural Development, Government of India New Delhi.

[5] Dubey, Kamlesh Kumar \& Pande, Subodh, Climate change and Food Security in India; Global Journal of Finance and Management, Research India Publication, New Delhi,(2012), p. 15-18.

[6] Das, D.K. Dynamics of Rural Development, Part-I, Deep and Deep Publications Pvt. New Delhi, (2007), PP. 113-120.

[7] Dreze, Jean. Poverty in India and the IRDP Delusion. 2009. Economic and Political Weekly. 